physicists who can not take quite this view with respect to our more firmly fixed theories of physics; probably the majority of metaphysicians would not acquiesce. It may be that some day reality will consist merely of conventions, or it may be that the pendulum will again swing to the other side and make the conventions real. At any rate much will still be spoken and written on both sides of the question.

E. B. WILson.

The Slide Rule. An Elementary Treatise. By J. J. Clank. Technical Supply Company, Scranton, Pa., and New York. $62 \mathrm{pp}$.

ONE familiar with algebra and logarithms usually needs little instruction in the use of the slide rule. He needs only practice in reading results accurately and expeditiously. On the other hand a person ignorant of logarithms finds the mastery of the instrument a more difficult task. The author of this booklet directs his attention to the wants of the latter class. His aim is to give directions for the use of the slide rule, so simple and explicit that any pupil with a fair knowledge of arithmetic can understand them. In this laudable purpose the author has been eminently successful. The booklet is a model of clear exposition.

The author confines his attention to two slide rules, the Mannheim rule and the Rietz rule. The term "Mannheim rule" has become generic. The Mannheim type is now used more than any other for ordinary purposes, and is manufactured by many firms in different countries. The name Rietz is attached to a specific rule, manufactured by the firm of Albert Nestler in Lahr, Baden. The Rietz rule is one of the very numerous rules with the Mannheim arrangement of the lines $A, B, C, D$, to which one or more other lines are added (in this case the $E$ line for cube root, etc.). Just why this Rietz rule should have been selected out of a very large number of similar domestic and foreign makes is not quite evident.

The author gives nothing on the history of the slide rule. It is perhaps just as well that no attempt should have been made in this line. Only very recently have I been able to settle the long-disputed question as to the inventor of the straight-edge slide rule.* Mr. Clark gives in his book just

* "History of the logarithmic slide rule," Engineering News Publ. Co., New York, 1909. 
four words of biographical information, but in so doing he comes to grief. Mannheim was not "a German army officer." As a young man he was a French army officer, and for about half a century he was professor in the Polytechnic School in Paris.

Florian Cajori.

Annuaire du Bureau des Longitudes pour l'An 1910, Paris. Gauthier-Villars.

THIs handy little volume makes its annual appearance as usual in good time. So far as we know there is nothing approaching to it in completeness for giving the astronomical, physical, electrical, meteorological, magnetic, and chemical constants. And what is of even more importance, everything is easy to find and the matter is constantly kept up to date. For the construction of problems in which one wishes to insert numerical data, the hunting in various books can be avoided and much time saved by having the Annuaire at hand. Two consecutive volumes give everything likely to be needed.

The principal appendix this year is an article on earth tides and the elasticity of the globe by M. Ch. Lallemand. A full historical survey of our knowledge up to the present time forms one of its most useful features. M. B. Baillaud tells of the work done at the last international conference on the photographic chart of the sky, and M. G. Bigourdan appends a list of all the Notices which have appeared in the Annuaire since its foundation in 1796 .

Ernest W. Brown.

\section{NOTES ON THE INSTITUT DE FRANCE AND THE ANNUAL MEETING OF THE ACADEMIE DES SCIENCES.}

IT is not generally known in America that the Institut de France is made up of five distinct bodies, known as the Académie Française, the Académie des Sciences, the Acadẻmie des Inscriptions et Belles-Lettres, the Académie des Sciences Morales et Politiques and the Académie des Beaux-Arts. Each of these academies has 40 members, with the exception of the Académie des Sciences which - in addition to its two permanent secretaries, one in each of the departments, physics and 